Check for updates

Cite this: RSC Adv., 2017, 7, 53454

Received 10th October 2017

Accepted 15th November 2017

DOI: $10.1039 / c 7 r a 11151 g$

rsc.li/rsc-advances

\section{Denitrification of groundwater using a biodegradable polymer as a carbon source: long- term performance and microbial diversity}

\begin{abstract}
Libing $\mathrm{Chu}^{\mathrm{a}}$ and Jianlong Wang (D) *ab
Nitrate pollution in groundwater is a worldwide problem. This paper reports on the denitrifying performance of using the biodegradable polymer polybutylene succinate (PBS) as a biofilm medium and carbon source to remove nitrate from groundwater via a packed bed bioreactor which was operated continuously for nearly 2 years. Results showed that the effluent nitrate concentration reached $3.3-8.8 \mathrm{mg} \mathrm{L}^{-1}$ and $88-97 \%$ of nitrate removal was achieved. The denitrification rate range was $0.25-0.35 \mathrm{~g} \mathrm{~N}$ per $\mathrm{L}$ per $\mathrm{d}$ at $20-29^{\circ} \mathrm{C}$ and decreased to $0.12 \mathrm{~g} \mathrm{~N}$ per $\mathrm{L}$ per $\mathrm{d}$ at $10-18{ }^{\circ} \mathrm{C}$. According to microelectrode analysis, the nitrate consumption rate $\left(1069 \pm 103 \mu \mathrm{mol} \mathrm{cm} \mathrm{cm}^{-1} \mathrm{~h}^{-1}\right)$ was much higher than the ammonium production rate (74 $\pm 7 \mu \mathrm{mol} \mathrm{cm} \mathrm{cm}^{-1} \mathrm{~h}^{-1}$, which proved that denitrification plays the major role in the system. A low level of DOC $\left(1.7 \pm 0.6 \mathrm{mg} \mathrm{L}^{-1}\right)$ and ammonium $\left(0.5 \pm 0.3 \mathrm{mg} \mathrm{L}^{-1}\right)$ was observed in the effluent, which was beneficial for practical application. The consumption rate of PBS was $2.75 \pm 0.72 \mathrm{~g} \mathrm{PBS} / \mathrm{g} \mathrm{NO}{ }_{3}-\mathrm{N}_{\text {removed }}$. In the attached biofilm, Proteobacteria, Betaproteobacteria, Burkholderiales and Comamonadaceae were the major phyla $(75.6 \%)$, classes $(59.8 \%)$, orders $(42.3 \%)$ and families $(42.2 \%)$ in each level. In the top 20 genera accounting for $25 \%$ of total sequences, 9 genera including Simplicispira, Comamonadaceae, Hydrogenophaga and Rhodocyclaceae were affiliated with denitrifying groups with an abundance of $16 \%$, whereas the bacteria belonging to the other 11 genera including Veillonellaceae, Propionivibrio and Bdellovibrio were reported to have the function of degradation and acidification of organic substance and might serve for degrading PBS in the system. The PBS solid-phase denitrification is promising for removing nitrate from groundwater.
\end{abstract}

\section{Introduction}

Nitrate is naturally present in the environment as part of the nitrogen cycle. However, anthropogenic inputs, such as the agricultural application of nitrogenous fertilizers and wastewater emission, have greatly increased the nitrate loads in receiving waters, leading to potential risks to the shallow and deep groundwater aquifers. ${ }^{1-3}$ Drinking nitrate-contaminated groundwater has the risks of methaemoglobinaemia for infants and stomach cancer. ${ }^{4}$ The maximum permissible level of nitrate in drinking water was set as $10 \mathrm{mg} \mathrm{N}$ per L by the U.S. Environmental Protection Agency ${ }^{5}$ and in the standard for drinking water quality of China (GB 5749-2006) to reduce the risks to human health.

Compared to the methods commonly used for nitrate removal such as ion-exchange, distillation, reverse osmosis and electrodialysis, heterotrophic biological denitrification is a cost-

${ }^{a}$ Collaborative Innovation Center for Advanced Nuclear Energy Technology, INET, Tsinghua University, Energy Science Building, Beijing 100084, P. R. China. E-mail: wangjl@tsinghua.edu.cn; Fax: +8610 62771150; Tel: +861062784843

${ }^{b}$ Beijing Key Laboratory of Radioactive Waste Treatment, Tsinghua University, Beijing 100084, P. R. China effective and practical on large-scale technology. ${ }^{6}$ The denitrifying microbes utilize organic substrates such as methanol, glucose and acetic acid that serve as electron donor and energy source, and convert nitrate into nitrogen gas under anoxic conditions. ${ }^{7,8}$

In recent years, solid-phase denitrification, which uses water insoluble solid materials as carbon substrates for denitrification and biofilm media, has been developed to eliminate nitrate from groundwater in situ or ex situ, ${ }^{9-11}$ aquaculture effluent, ${ }^{12,13}$ and biologically treated effluent. ${ }^{14}$ There exist two kinds of solid carbon source: the natural plant materials such as woodchips, straws and reeds ${ }^{\mathbf{1 5 , 1 6}}$ and the synthetic biodegradable polymers such as polycaprolactone (PCL), polybutylene succinate (PBS), polylactic acid and polyhydroxyalkanoate. ${ }^{\mathbf{1 7 - 2 2}}$

Healy et al. ${ }^{11}$ investigated nitrate removal from groundwater by solid-phase denitrification using woodchips, pine needles, barley straw and cardboard, respectively as carbon source and media. The nitrate removal efficiency reached $67-89 \%$ at steadystate operation and the bioreactor filled with woodchips demonstrated less adverse effects such as dissolved organic carbon (DOC) release. Gibert et $a .^{23}$ built a permeable reactive barrier filled with softwood for in situ groundwater remediation. More than $98 \%$ of nitrate removal was obtained with the 
denitrification rate of $0.067 \mathrm{mg} \mathrm{N}$ per L per d per $\mathrm{g}_{\text {substrate }} \mathrm{Wu}$ et al. ${ }^{24}$ reported that the nitrate removal reached $95 \%$ in a solidphase denitrification system using PBS as carbon source to treat drinking water at $25{ }^{\circ} \mathrm{C}$. Boley et al. ${ }^{25}$ studied the treatment of wastewater from a recirculating aquaculture system with eels by a fluidized bed reactor filled with PCL for denitrification carbon source. The effluent nitrate concentration remained at low levels of 3-10 mg $\mathrm{N}$ per $\mathrm{L}$, whereas a nitrate accumulation of $200 \mathrm{mg} \mathrm{N}$ per L was observed in the control system without denitrification treatment.

Solid-phase denitrification using biopolymers as carbon source is especially attractive in groundwater treatment due to the good and stable denitrifying performance and effluent quality such as low levels of DOC and color release. ${ }^{26}$ The high production cost of the biopolymers is the major factor to limit its application. Among the biopolymers available, PBS denitrification is drawing increasingly attention owing to the good biodegradability and economics. ${ }^{24,27}$ In addition, most studies related to biopolymer solid-phase denitrification are operated in batch mode or continuously for a short time (3-8 months). For commercial application, the denitrifying performance and degradation properties of biopolymers during a long-term run should be studied.

In the present study, a PBS-packed bioreactor was established to eliminate nitrate in groundwater. The long-term performance of the bioreactor for nearly 2 years was evaluated in terms of nitrate removal, denitrification rate, and the quality of the treated groundwater. The characteristics of PBS degradation and the biofilm attached as well as the bacterial community were analyzed. The results of this study could enrich our understanding on solid-phase denitrification and provide a reference for its practical application in the management of groundwater nitrate pollution.

\section{Materials and methods}

\section{PBS media}

The granules of PBS used are cylindrical with an average diameter of $3.0 \mathrm{~mm}$. The density and specific surface are $1.24 \mathrm{~kg}$ $\mathrm{L}^{-1}$ and $0.826 \mathrm{~m}^{2} \mathrm{~g}^{-1}$, respectively. The chemical structure of PBS is as follows:

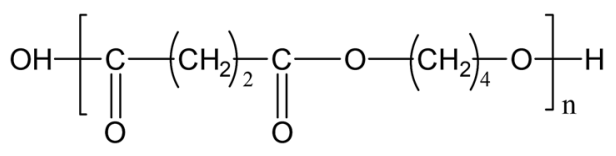

\section{Experimental set-up and procedures}

A packed bed reactor consisting of a cylindrical Plexiglas vessel (working volume $3.0 \mathrm{~L}$ ) was established (Fig. 1). The packing ratio of PBS granules was $56.3 \%(\mathrm{v} / \mathrm{v})$. A sieve was inserted into the reactor to prevent washout of PBS granules. Influent was continuously pumped into the bottom of reactor and effluent was discharged from overflow. The denitrification reactor was seeded with anoxic sludge collected from a municipal wastewater treatment plant with the concentration of $1500 \mathrm{mg}$ total suspended

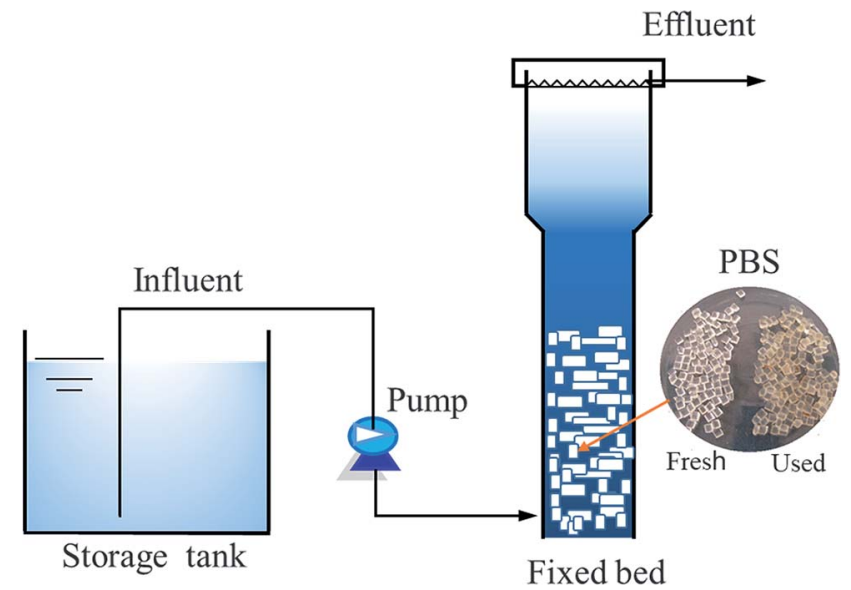

Fig. 1 The schematic diagram of the experimental set-up.

solids (TSS) per L. The initial hydraulic retention time (HRT) was $41 \mathrm{~h}$ and temperature was $20^{\circ} \mathrm{C}$. During the long-term operation of nearly 2 years, the temperature fluctuated in the range of 29$10{ }^{\circ} \mathrm{C}$ with the seasons (Fig. 2). The HRT was decreased gradually to $4.5 \mathrm{~h}$ and then varied in 5.6-13 $\mathrm{h}$, depending on the performance of the reactor at different temperatures. Samples were periodically taken throughout the experiment to evaluate $\mathrm{NO}_{3}-\mathrm{N}$, $\mathrm{NO}_{2}-\mathrm{N}$ and $\mathrm{NH}_{4}-\mathrm{N}$ and DOC content in the effluent. Biofilm samples were taken at about 500 days to do DNA extraction, PCR amplification and pyrosequencing.

\section{Influent characteristics}

The groundwater was exploited from Changping district, Beijing. The content of $\mathrm{NO}_{3}-\mathrm{N}, \mathrm{NO}_{2}-\mathrm{N}$ and $\mathrm{NH}_{4}-\mathrm{N}$ and DOC were 10-13 $\mathrm{mg} \mathrm{L}^{-1}$, less than $0.09 \mathrm{mg} \mathrm{L}^{-1}, 0.17 \mathrm{mg} \mathrm{L}^{-1}$ and $0.3 \mathrm{mg} \mathrm{L}^{-1}$, respectively. The following metal ions $\left(\mathrm{mg} \mathrm{L}^{-1}\right)$ were detected: $\mathrm{Ca}^{2+}, 69 ; \mathrm{Mg}^{2+}, 41 ; \mathrm{Na}^{+}, 13 ; \mathrm{K}^{+}, 2.1 ; \mathrm{Mn}^{2+}, 0.2$. The groundwater was fed into the PBS bioreactor by spiking with $\mathrm{NaNO}_{3}$ and $\mathrm{kH}_{2} \mathrm{PO}_{4}$ to reach the influent $\mathrm{NO}_{3}-\mathrm{N}$ concentration

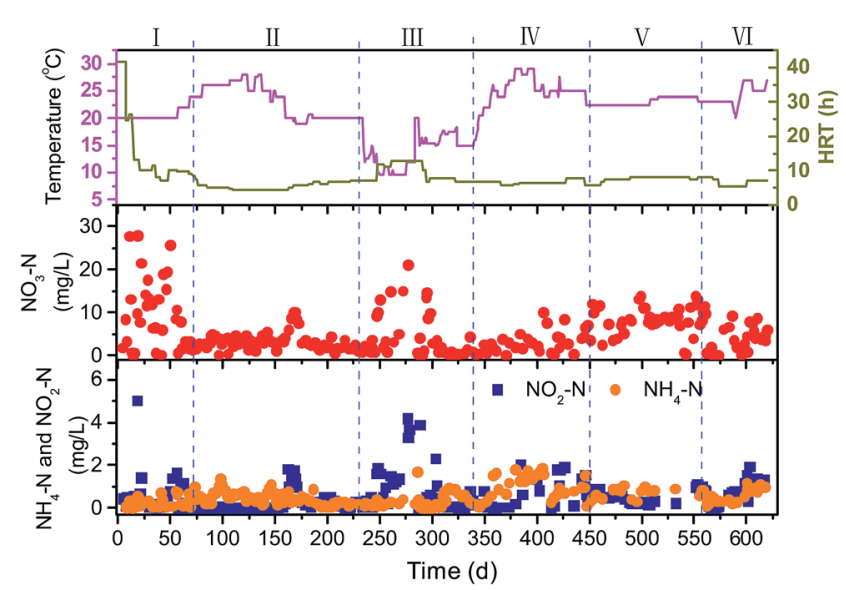

Fig. 2 Variation of temperature, HRT and effluent nitrogen concentrations with time. 
of $68 \pm 2 \mathrm{mg} \mathrm{L}^{-1}$ and TP levels of $1.1 \pm 0.2 \mathrm{mg} \mathrm{L}^{-1}$, respectively. The $\mathrm{pH}$ value of the influent was $7.8 \pm 0.1$.

\section{Batch assays}

After a certain period (1-2 months), batch tests were conducted to determine the specific denitrification rate (SDNR) of the biofilm attached to PBS media as described in previous studies. ${ }^{28}$ The temperature was kept at $28.5{ }^{\circ} \mathrm{C}$. The SDNR was determined using linear regressions fitted to plots of decreasing nitrate concentration $v s$. time divided by the initial volatile suspended solid (VSS) content (mg N/g VSS per d). The changes in the weight per piece of PBS granule and the biofilm concentration ( $\mathrm{g}$ VSS per L) were also evaluated.

\section{Analytic methods}

$\mathrm{NH}_{4}-\mathrm{N}, \mathrm{NO}_{2}-\mathrm{N}$ and $\mathrm{NO}_{3}-\mathrm{N}$ were measured according to Chinese SEPA Standard Methods. ${ }^{29}$ DOC was determined by a multi N/C 2100 model TOC/TN analyzer (Analytic Jena, Germany). Three-dimensional excitation-emission matrix (3DEEM) fluorescence spectroscopy was applied to analyze the characterization of dissolved organic matter in the effluent using a spectrometry (F-7000 fluorescence spectrophotometer, Hitachi Japan).

The molecular weight (MW) distribution of organic matters in the effluent was evaluated by a HPLC system (LC-20A, Shimadzu, Japan) equipped with a UV detector and an SEC column (TSK-GEL G3000PWXL). Sodium polystyrene sulphonate (3-30 $\mathrm{kDa}$ ) and acetone (58 Da) were used as the standard solutions for $M_{\mathrm{W}}$ calibration curve construction.

The functional groups of PBS granules were characterized using one NTS FT-IR spectrometer (PerkinElmer Spectrum). The structure of the PBS granules and biofilm attached was observed by a JSM- 6700F scanning electron microscopy (SEM, JEOL, Japan).

Biofilm adhered to the PBS granules was collected by ultrasonic (40 kHz, $5 \mathrm{~min}$ ). The content of TSS and VSS of the biofilm samples were evaluated using gravimetric method. ${ }^{29}$ The extracellular polymer substances (EPS) were analyzed by the formaldehyde- $\mathrm{NaOH}$ extraction method. ${ }^{30}$ The content of carbon, oxygen, nitrogen and hydrogen element was quantified by an Vario EL element analyzer (Elementar, Germany).

For analysis of bacterial communities in the biofilm samples, after DNA extraction and purification, PCR amplification, amplicon quantitation and pooling, the pyrosequencing was conducted using a 454 Life Sciences Genome Sequencer FLX instrument (Roche, NJ, USA) by Majorbio Bio-pharm Biotechnology Company (Shanghai, China). Analysis of sequencing data were performed using Mothur software.

The liquid-membrane microelectrodes sensitive to nitrate anions and ammonium ions were prepared, respectively to detect the profiles of nitrate and ammonium within biofilm. Briefly, the nitrate and ammonium microelectrodes with a tip diameter of 5 $\mu \mathrm{m}$ and $15 \mu \mathrm{m}$, respectively were moved from the surface to the inner part of biofilm by a motor-driven micromanipulator. The output signals were transformed and recorded by computer using SensorTtrace Pro 2.0 software (Unisense, Denmark). The nitrate consumption rate and ammonium production rate were calculated using Fick's second law of diffusion. ${ }^{31}$ The applied molecular diffusion coefficients of nitrate and ammonium were $1.1 \times 10^{-5}$ and $1.38 \times 10^{-5} \mathrm{~cm}^{2} \mathrm{~s}^{-1}$, respectively. ${ }^{32}$

\section{Results and discussion}

\section{Performance of PBS-packed bed bioreactor}

Fig. 2 shows the variation of operational parameters and the overall performance of the PBS-packed bed reactor with respect to the concentrations of effluent $\mathrm{NO}_{3}-\mathrm{N}, \mathrm{NH}_{4}-\mathrm{N}$ and $\mathrm{NO}_{2}-\mathrm{N}$ during the long-term operation of $620 \mathrm{~d}$. The operational conditions and denitrification rate in the different phases were summarized in Table 1.

The effluent $\mathrm{NO}_{3}-\mathrm{N}$ concentration decreased on the third day from start-up and then HRT was reduced gradually. After 2 months of operation (Phase 1), the reactor was started up successfully and $\mathrm{NO}_{3}-\mathrm{N}$ removal reached $90 \%$. Thereafter, the reactor was operated at temperatures of $20-28{ }^{\circ} \mathrm{C}$ and HRT of 5$7 \mathrm{~h}$ (Phase 2), the effluent nitrate maintained at low levels of around $3.0 \mathrm{mg} \mathrm{L}{ }^{-1}$ with $\mathrm{NO}_{3}-\mathrm{N}$ removal efficiency of higher than $95 \%$. The denitrification rate reached the highest level of $0.35 \mathrm{~g} \mathrm{~N}$ per L per d. As the operation temperature dropped to $10-18{ }^{\circ} \mathrm{C}$ (Phase 3), the nitrate removal efficiency decreased to $87.7 \%$ even extending HRT to $12-13 \mathrm{~h}$. A nitrite accumulation was also found. The denitrification rate decreased by $65 \%$ compared to that in phase 2 . When the temperature of the reactor rose to more than $20{ }^{\circ} \mathrm{C}$ (Phase 4), the nitrate removal efficiency and denitrification rate recovered to more than $95 \%$ and $0.25 \mathrm{~g} \mathrm{~N}$ per L per d, respectively. After 1.5 years of experiment (Phase 5), the concentration of effluent $\mathrm{NO}_{3}-\mathrm{N}$ increased remarkably, which might be attributed to the great degradation of PBS carbon source and the increased biofilm density which limited the mass transfer of both nitrate and substrate. Therefore, $200 \mathrm{~g}$ of fresh PBS granules, which equals to $15 \%$ of the initial amount, was replenished to the reactor (Phase 6). The effluent nitrate decreased rapidly and $94 \%$ of nitrate removal was obtained after PBS addition. It is obvious that renewal of the fresh carbon source after some period of time is necessary for the continuous operation.

Only a small increase in effluent DOC of $1.7 \pm 0.6 \mathrm{mg} \mathrm{L}^{-1}$ was observed during the long-term operation, which is much lower than that using PCL of 1.7-5.2 $\mathrm{mg} \mathrm{L}^{-1}$ (ref. 9) and poly-3hydroxybutyrate-co-hyroxyvelate (PHBV) of $14.9 \pm 5.5 \mathrm{mg} \mathrm{L}^{-1}$ (ref. 22) as carbon source for denitrification in treating the similar groundwater. This is promising for practical applications because the burden of post treatment to polish the effluent is reduced. The MW distributions of the DOC in the effluent revealed four fractions, 3.31, 2.32, 1.27 and dominant $0.83 \mathrm{kDa}$. The calculated $M_{\mathrm{w}}$ and $M_{\mathrm{n}}$ were 1.55 and $1.14 \mathrm{kDa}$, respectively. The effluent mainly contained soluble microbial products-like substances from 3D-EEM spectrum (spectrum not shown). The $\mathrm{pH}$ values and TP concentration in the effluent were $8.0 \pm 0.1$ and $0.5 \pm 0.2 \mathrm{mg} \mathrm{L}^{-1}$, respectively.

It is reported that temperature is one of the important factors controlling solid-phase denitrification, in addition to HRT, influent nitrate concentration and $\mathrm{pH}$, dissolved oxygen (DO), 
Table 1 The operational parameters and performance of the PBS-packed reactor in the different phases

\begin{tabular}{|c|c|c|c|c|c|c|}
\hline & Phase 1 & Phase 2 & Phase 3 & Phase 4 & Phase 5 & Phase 6 \\
\hline \multicolumn{7}{|l|}{ Conditions } \\
\hline Time (d) & $0-70$ & $71-231$ & $232-335$ & $336-449$ & $450-560$ & $561-620$ \\
\hline Temperature $\left({ }^{\circ} \mathrm{C}\right)$ & $20-22$ & $20-28$ & $10-18$ & $20-29$ & $23-24$ & $23-27$ \\
\hline HRT (h) & $41-10$ & $5-7$ & $12-13$ & $6-8$ & $6-8$ & $6-8$ \\
\hline \multicolumn{7}{|l|}{ Effluent } \\
\hline $\mathrm{NO}_{3}-\mathrm{N}\left(\mathrm{mg} \mathrm{L}^{-1}\right)$ & $10.7 \pm 9.1$ & $3.0 \pm 1.5$ & $8.8 \pm 6.9$ & $2.2 \pm 1.9$ & $8.4 \pm 3.2$ & $3.6 \pm 2.8$ \\
\hline $\mathrm{NO}_{2}-\mathrm{N}\left(\mathrm{mg} \mathrm{L}^{-1}\right)$ & $1.3 \pm 2.2$ & $0.1 \pm 0.1$ & $1.8 \pm 1.2$ & $0.5 \pm 0.5$ & $0.57 \pm 0.27$ & $0.79 \pm 0.61$ \\
\hline $\mathrm{NH}_{4}-\mathrm{N}\left(\mathrm{mg} \mathrm{L}^{-1}\right)$ & $0.3 \pm 0.3$ & $0.5 \pm 0.3$ & $0.2 \pm 0.1$ & $0.8 \pm 0.3$ & $0.72 \pm 0.23$ & $0.62 \pm 0.33$ \\
\hline Nitrate removal (\%) & $89.4 \pm 8.6$ & $96.1 \pm 2.6$ & $87.7 \pm 11.5$ & $96.9 \pm 2.8$ & $86.5 \pm 5.0$ & $94.2 \pm 4.2$ \\
\hline Denitrification rate ( $\mathrm{g} \mathrm{N}$ per L per $\mathrm{d}$ ) & $0.16 \pm 0.02$ & $0.35 \pm 0.03$ & $0.12 \pm 0.02$ & $0.25 \pm 0.04$ & $0.17 \pm 0.03$ & $0.22 \pm 0.04$ \\
\hline
\end{tabular}

etc. ${ }^{26,33}$ The DO concentration detected in the influent was around $1.5 \mathrm{mg} \mathrm{L}^{-1}$, which was consumed quickly though PBSpacked bioreactor, leading to low DO levels in the effluent (less than $0.3 \mathrm{mg} \mathrm{L}^{-1}$ ) that was appropriate for denitrification. The denitrification rate in the PBS-packed reactor was lower by $52-66 \%$ at temperatures of $10-18{ }^{\circ} \mathrm{C}$ than that at $20-29^{\circ} \mathrm{C}$. The solid carbon source could not be utilized directly by denitrifying bacteria but needs to be hydrolyzed into soluble and micromolecular substrates. Both the hydrolysis efficiency of PBS and the activities of the denitrifying microbes declined with decreasing temperature, ${ }^{34}$ leading to a reduction in denitrification rate. Our previous studies showed that the denitrification rate decreased by around $50 \%$ with a $5{ }^{\circ} \mathrm{C}$ reduction in PCLpacked denitrification reactor. ${ }^{9}$ Cameron and Schipper ${ }^{35}$ documented that the $\mathrm{NO}_{3}-\mathrm{N}$ removal rate was raised by 1.7 times when temperature was increased by $10{ }^{\circ} \mathrm{C}$ using the softwoodspacked denitrification bed.

Nitrite is an intermediate of denitrification process. As shown in Fig. 2 and Table $1, \mathrm{NO}_{2}-\mathrm{N}$ accumulation was observed in the effluent during the initial stage (Phase 1 , around $1.3 \mathrm{mg} \mathrm{L}^{-1}$ ) and the operation at the lower temperatures (Phase 3, around $1.8 \mathrm{mg} \mathrm{L}^{-1}$ ) owing to the incomplete denitrification. In the most period, the $\mathrm{NO}_{2}-\mathrm{N}$ concentration in the effluent were less than $0.9 \mathrm{mg} \mathrm{L}^{-1}$. The concentration of leached ammonium in the effluent was at low levels $\left(0.5 \pm 0.3 \mathrm{mg} \mathrm{L}^{-1}\right)$ throughout the total operation. This indicates that heterotrophic denitrification of reducing nitrate to nitrogen gas was predominant in the system using PBS as carbon source. It is known that there is another pathway, dissimilatory nitrate reduction to ammonium (DNRA), which competes with denitrification for nitrate. ${ }^{36}$ Microelectrode data indicated that ammonium production was detected at the biofilm-media interface and $\mathrm{NH}_{4}-\mathrm{N}$ concentration decreased toward the bulk surface, while $\mathrm{NO}_{3}-\mathrm{N}$ concentration decreased gradually from the biofilm-bulk interface toward the biofilm bottom (Fig. 3). The calculated nitrate consumption rate (1069 \pm $103 \mu \mathrm{mol} \mathrm{cm} \mathrm{cm}^{-1} \mathrm{~h}^{-1}$ ) was much higher than the ammonium production rate $\left(74 \pm 7 \mu \mathrm{mol} \mathrm{cm}{ }^{-1} \mathrm{~h}^{-1}\right)$, which proved that denitrification plays the major role in the system.

\section{Characterization of PBS degradation and biofilm attachment}

From batch test, the weight of each piece of PBS granule declined almost linearly over the course of time (Fig. 4). The degradation rate of PBS was around $0.04 \mathrm{mg} \mathrm{d}^{-1}$. If the useful life of the solid carbon source is $50 \%$ of its initial weight, the PBS granules (with the initial weight of around $0.0289 \mathrm{~g}$ per piece) would last around 1 year, after that period refreshing some carbon source seems to be needed.

From SEM observation, the fresh PBS granule has relatively smooth surface with some protuberances (Fig. 5a), while the used PBS has concave cavities induced by microbial corrosion (Fig. 5b). According to FT-IR spectra (Fig. 6), PBS exhibits the characteristic adsorption at $2961 \mathrm{~cm}^{-1}, 2944 \mathrm{~cm}^{-1}$ and $2850 \mathrm{~cm}^{-1}$ due to $\mathrm{CH}_{2}$ stretching vibration, $1713 \mathrm{~cm}^{-1}$ assigned to carbonyl group, $1174 \mathrm{~cm}^{-1}$ and $955 \mathrm{~cm}^{-1}$ due to $\mathrm{C}-\mathrm{O}$ stretching vibration and $1044 \mathrm{~cm}^{-1}$ assigned to $\mathrm{O}\left[\mathrm{CH}_{2}\right]_{4} \mathrm{O}$ group. After PBS was used as carbon source, a broad peak in $3000-3750 \mathrm{~cm}^{-1}$ region assigned to hydroxyl group has become obviously, indicating that there existed small fragments from PBS hydrolysis. The shape and position of the characteristic adsorption of the used PBS were similar to that of the fresh PBS, whereas the peak intensities declined greatly due to biodegradation.

When acting as carriers, PBS favors the attachment of biofilm which was composed of cocci and rod shape bacteria with some filamentous bacteria (Fig. 5c). The amount of biofilm

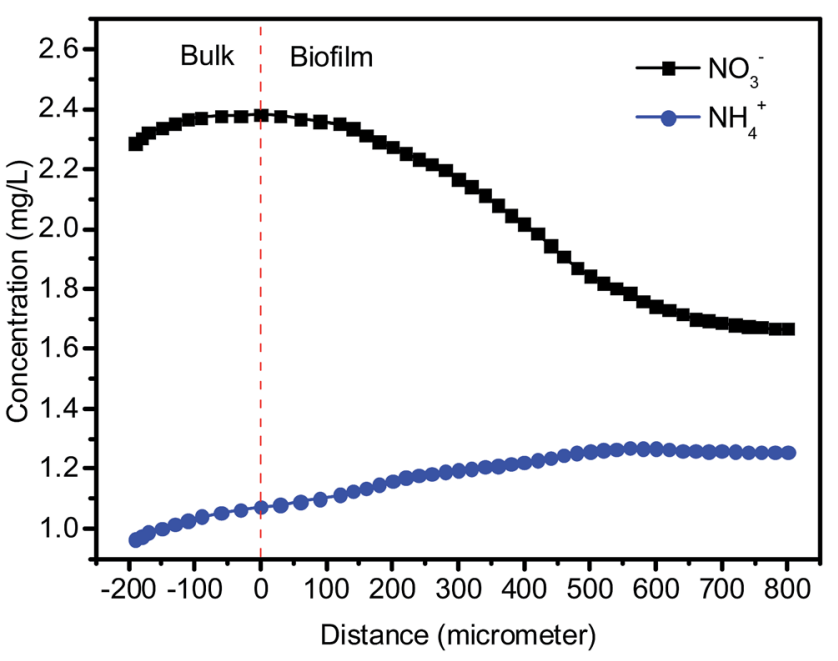

Fig. 3 Micro-profiles of nitrate and ammonium concentrations. 


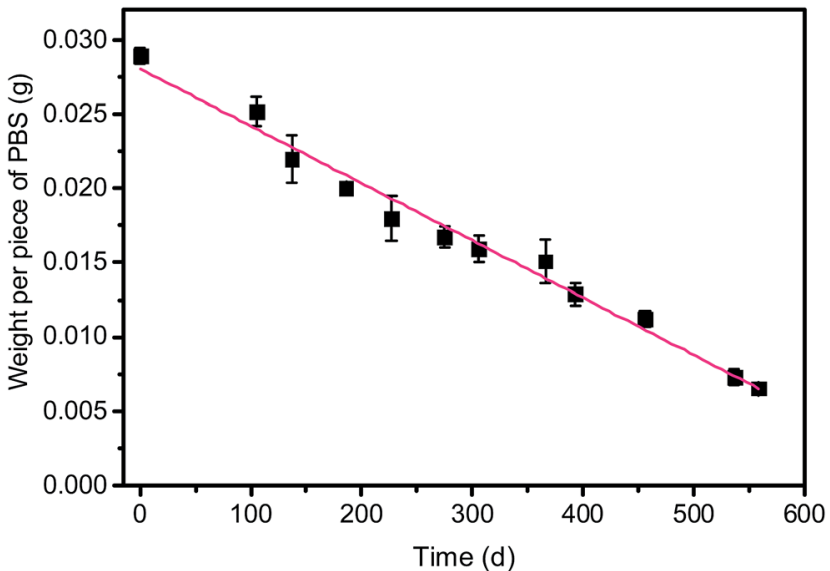

Fig. 4 Changes in weight per piece of PBS with operation time.

attached to PBS media increased gradually with the prolonged operating time and reached around $16 \mathrm{~g}$ VSS per $\mathrm{L}$ after 1 year of operation. With the increase in the biofilm density the mass transfer of both nitrate and substrate might be limited. Consequently, the SDNR of biofilm attached initially decreased remarkably and then stabilized at around $0.03 \mathrm{mg} \mathrm{N} / \mathrm{g}$ VSS per d (Fig. 7). It is noted that the VSS/TSS ratio of biofilm reached more than $90 \%$, indicating the high activity of biofilm attached to the biodegradable media. Similar results were found in a denitrification reactor using PCL as carbon source. ${ }^{9}$ In the EPS composition, the content of protein (129 $\pm 12 \mathrm{mg}$ per $\mathrm{g}$ VSS) was much higher than that of polysaccharides ( $41 \pm 5 \mathrm{mg}$ per $\mathrm{g}$ VSS), which might be owing to the excretion of cytosolic proteins or cell lysis. ${ }^{37}$

When PBS was utilized as carbon source for denitrification, the reaction of PBS monomer with nitrate leads to the production of carbon dioxide, nitrogen gas and biomass. The elemental composition of biomass was $\mathrm{C}_{3.87} \mathrm{H}_{6.86} \mathrm{~N}_{0.67} \mathrm{O}_{2.14}$ from the elemental analysis of biofilm. Assuming a yield $0.45 \mathrm{~g}$ biomass $/ \mathrm{g}$ PBS ${ }^{38}$ the equation of denitrification reaction can be given as:

$$
\begin{aligned}
& 4.857 \mathrm{NO}_{3}{ }^{-}+\mathrm{C}_{8} \mathrm{O}_{4} \mathrm{H}_{12}+4.587 \mathrm{H}^{+} \rightarrow \\
& 0.724 \mathrm{C}_{3.87} \mathrm{H}_{6.86} \mathrm{~N}_{0.67} \mathrm{O}_{2.14}+2.05 \mathrm{~N}_{2}+5.2 \mathrm{CO}_{2}+5.81 \mathrm{H}_{2} \mathrm{O}
\end{aligned}
$$

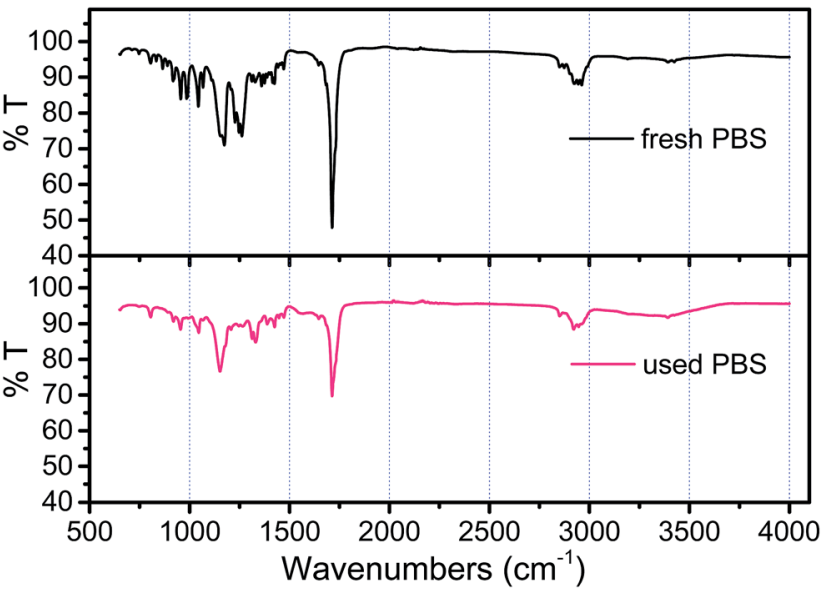

Fig. 6 FT-IR spectrum of the fresh and used PBS.

The theoretical amount of PBS consumed in removing a gram of $\mathrm{NO}_{3}-\mathrm{N}$ was $2.68 \mathrm{~g} \mathrm{PBS} / \mathrm{g} \mathrm{NO}_{3}-\mathrm{N}$. The practical PBS consumption rate $\left(2.75 \pm 0.72 \mathrm{~g}\right.$ PBS/g $\left.\mathrm{NO}_{3}-\mathrm{N}\right)$ was slightly higher than the theoretical value. Similar results were also found by other researchers who utilized PCL and poly-3hydroxybutyric acid (PHB) as denitrifying carbon source..$^{13,25}$ This difference might be due to the residual oxygen consumption on carbon source. In the presence of dissolved oxygen, a portion of carbon source was consumed by aerobic respiration instead of denitrification. ${ }^{25}$

The unit price of the domestic PBS products in China ranges $18-25 \mathrm{CNY} / \mathrm{kg}$. The calculated denitrification cost using PBS as carbon source was $49-68 \mathrm{CNY} / \mathrm{kg} \mathrm{NO}_{3}-\mathrm{N}$, which are higher than using methanol. ${ }^{22}$ If the economic PBS polymers were available with the development of bioplastic industry, PBS solid-phase denitrification might be competitive in practical application.

\section{Microbial community analysis}

The numbers of effective sequence tags obtained from pyrosequencing were 13950 . Fig. 8 shows the bacterial community and abundance identified at the phylum, class, order and family levels in biofilm attached. At the phylum level, Proteobacteria was predominant with relative abundance of $75.6 \%$, followed by
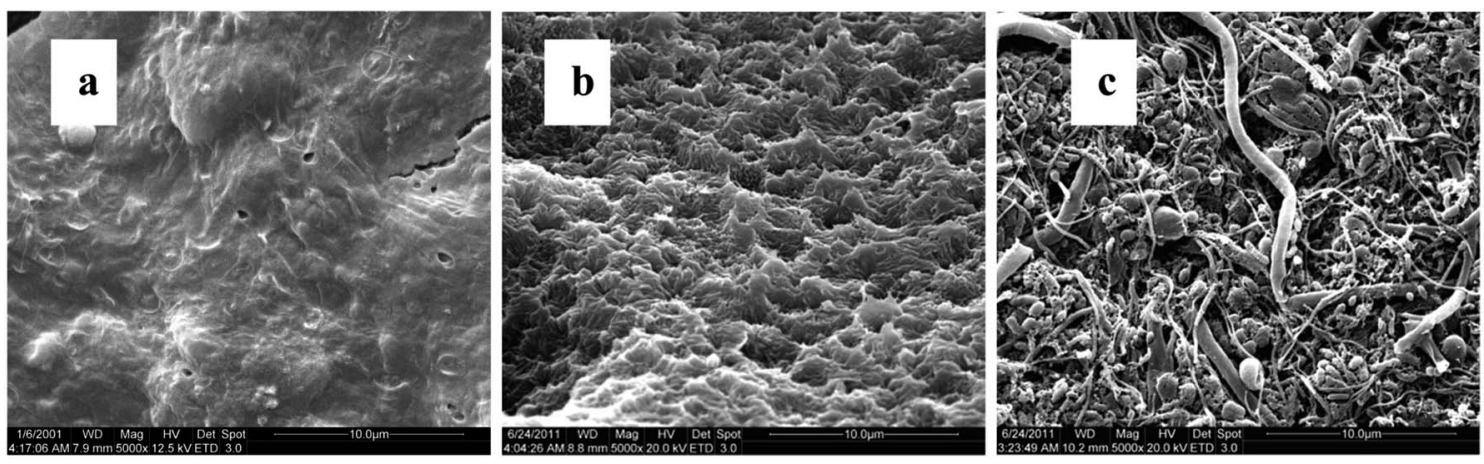

Fig. 5 SEM images of PBS granule, fresh (a) and used (b) and biofilm attached (c). 


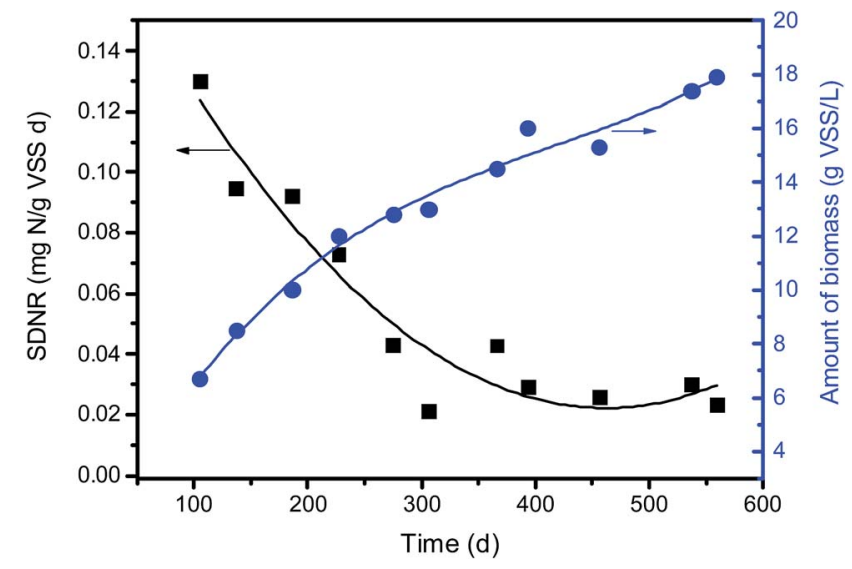

Fig. 7 Changes in SDNR and the amount of attached biomass with time.

Bacteroidetes (5.62\%), Firmicutes (4.32\%), Chlorobi (4.14\%) and Spirochaetes (0.8\%). Betaproteobacteria, Burkholderiales and Comamonadaceae were the major classes (59.8\%), orders (42.3\%) and families (42.2\%) in each level, respectively. Hiraishi and $\mathrm{Khan}^{38}$ have documented that most of the PHA-degrading denitrifying bacteria were affiliated to Betaproteobacteria and family Comamonadaceae. Khan et al. ${ }^{39}$ have isolated 23 strains of PHBV-degrading denitrifying bacteria from different activated sludge. 16S ribosomal DNA sequence analysis demonstrated that 20 of the strains belonged to the family Comamonadaceae.

At the genus level, the identified bacteria of the major OTUs, the relative abundance and function reported were shown in Table 2. It is worthwhile to note that there were $71 \%$ of sequences unclassified in the biofilm samples. In the top 20 OTUs accounting for $25 \%$ of the total sequence, 9 OTUs involving Simplicispira, Comamonadaceae, Hydrogenophaga and Rhodocyclaceae belonged to denitrifying groups with an abundance of $16 \%$. All the genera of identified denitrifiers affiliated with phylum Proteobacteria. The abundance of genus Simplicispira was the highest. It was reported bacteria belonging to Simplicispira are able to reduce nitrate to nitrite and have been isolated from activated sludge in treating wastewater for inorganic nutrient removal. ${ }^{40}$ Ruan et al. ${ }^{41}$ also reported that the denitrifiers Azoarcus and Simplicispira were dominant in a recirculating aquaculture system filled with PBS as the biofilm carrier and carbon source for simultaneous removal of ammonium and nitrate. In addition, genus Desulfovibrio was found in the pyrosequencing analysis $(0.6 \%)$, which was reported to be able to reduce nitrate to ammonium. ${ }^{42}$ This is the reason why ammonium was detected in the effluent.

The denitrifiers using the solid carbon source were found to be different from that using the soluble carbon substrate. The denitrifying bacteria in the genera Diaphorobacter, Simplicispira and Comamonas which were found in the present study and Acidovorax belonging to family Comamonadaceae were commonly dominant in the solid-phase denitrification system..$^{12,43,44}$ The genera Pseudomonas, Paracoccus, Alcaligenes and Bacillus are the important groups of denitrifiers in the traditional denitrification system using soluble carbon source such as methanol and ethanol. ${ }^{45-47}$

As shown in Table 2, the bacteria including Veillonellaceae, Propionivibrio and Bdellovibrio, belonging to other 11 genera with an abundance of $9 \%$ were reported to have the function of degradation and acidification of organics. In the present study, they might serve for degrading PBS. The denitrifying microbes are not capable of utilizing the macromolecular PBS directly. In the solid-phase denitrification system there are microbes which secrete some hydrolases such as protease and lipases to
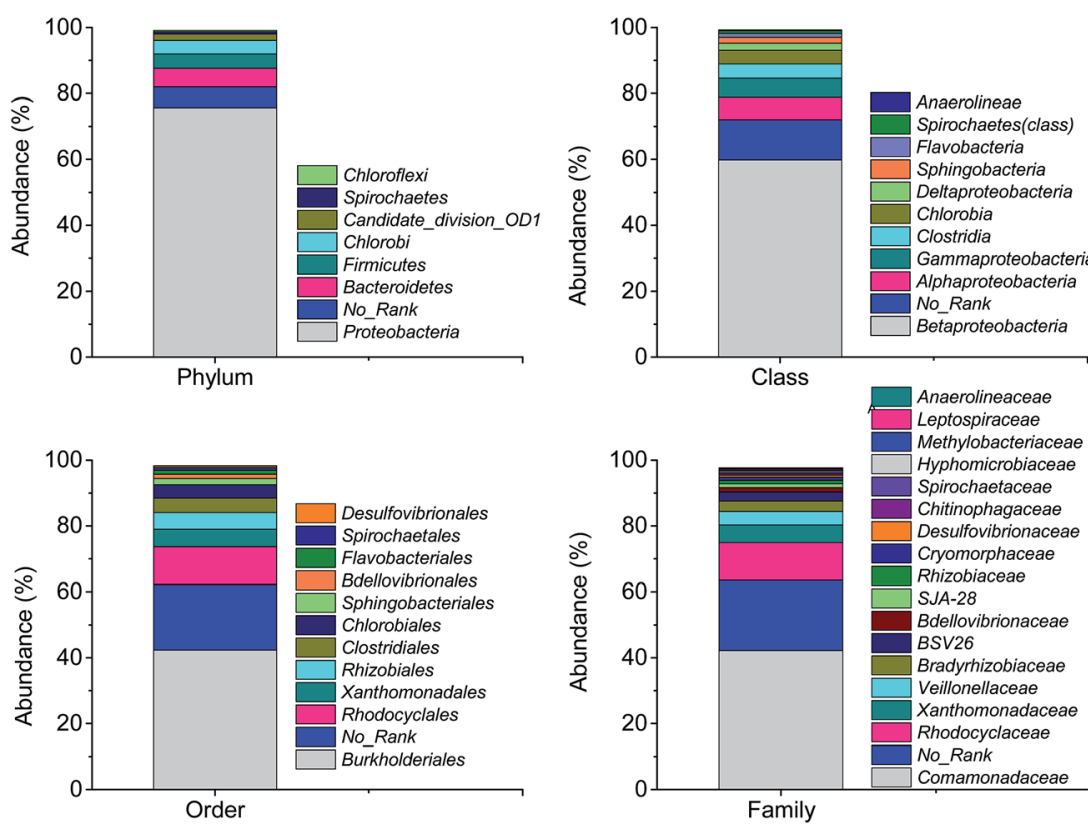

Fig. 8 The bacterial community and abundance at phylum, class, order and family levels in biofilm attached. 
Table 2 Bacterial identification of the major OTUs at genus level, the relative abundance, the phylogenetic affiliation and function ${ }^{a}$

\begin{tabular}{|c|c|c|c|c|c|}
\hline OTU & $\begin{array}{l}\text { Abundance } \\
(\%)\end{array}$ & Genus & Phylum/family & Function & Ref. \\
\hline 1 & 5.48 & Simplicispira $^{\star}$ & Proteobacteria/Comamonadaceae & Reduce nitrate to nitrite & 40 \\
\hline 3 & 3.86 & Comamonadaceae uncultured ${ }^{\star}$ & Proteobacteria/Comamonadaceae & Denitrification & 39 \\
\hline 4 & 2.95 & Hydrogenophaga ${ }^{\star}$ & Proteobacteria/Comamonadaceae & PHBV/PBS-degrading denitrifiers & $\begin{array}{l}24 \text { and } \\
39\end{array}$ \\
\hline 6 & 1.25 & Rhodocyclaceae uncultured ${ }^{\star}$ & Proteobacteria/Rhodocyclaceae & Reduce nitrate to nitrogen gas & 51 \\
\hline 7 & 1.08 & Bdellovibrio & Proteobacteria/Bdellovibrionaceae & Degrade macromolecules of their prey & 52 \\
\hline 8 & 0.95 & Rhizobium $^{\star}$ & Proteobacteria/Rhizobiaceae & Anaerobic denitrification & 53 \\
\hline 9 & 0.75 & Owenweeksia & Bacteroidetes/Cryomorphaceae & Aerobic oxidation metabolism & 54 \\
\hline 10 & 0.59 & Desulfovibrio $^{\star}$ & Proteobacteria/Desulfovibrionaceae & Reduce nitrate to ammonium & 42 \\
\hline 11 & 0.39 & Azospira $^{\star}$ & Proteobacteria/Rhodocyclaceae & Denitrifier isolated from activated sludge & 55 \\
\hline 15 & 0.29 & Blastochloris & Proteobacteria/Hyphomicrobiaceae & Phototrophs and nitrogen-fixers & 58 \\
\hline 16 & 0.26 & Ideonella & Proteobacteria/Comamonadaceae & $\begin{array}{l}\text { Enable to grow anaerobically by reducing } \\
\text { chlorate to chloride }\end{array}$ & 59 \\
\hline 17 & 0.24 & Anaerolineaceae uncultured & Chloroflexi/Anaerolineaceae & Degrade carbohydrate & 60 \\
\hline 18 & 0.22 & Leptospiraceae uncultured & Spirochaete/Leptospiraceae & Free-living saprophyte found in fresh water & 61 \\
\hline 19 & 0.12 & Diaphorobacter ${ }^{\star}$ & Proteobacteria/Comamonadaceae & PHB-degrading denitrifying & 62 \\
\hline 20 & 0.1 & Thiothrix $\star^{\star}$ & Proteobacteria/Thiotrichaceae & $\begin{array}{l}\text { Reduce nitrate to nitrite and/or further } \\
\text { to } \mathrm{N}_{2} \mathrm{O}\end{array}$ & 63 \\
\hline
\end{tabular}

decompose PBS to small soluble monomers. ${ }^{17,26}$ The degraded products were then utilized by denitrifying bacteria to achieve biological denitrification. It should be noted that some species of genus Diaphorobacter which was detected in the PBS solid-phase denitrification system, were reported to be characterized with both degrading PHBV and denitrification..$^{48}$ In addition, no methanogen microbes were observed in the current work. It is reported that in the solid-phase denitrification process, the organic solid substances might be degraded by anaerobic digestion, leading to the production of $\mathrm{CO}_{2}$ and $\mathrm{CH}_{4} \cdot{ }^{26} \mathrm{In}$ such cases, the methanogens might develop in the inner part of the carriers, which compete with denitrifies for carbon source.

\section{Conclusions}

The long-term performance of a PBS-packed bed bioreactor for nearly 2 years demonstrated that the system is promising to remove nitrate from groundwater. The effluent nitrate concentration reached $3.3-8.8 \mathrm{mg} \mathrm{L}^{-1}$ and $88-97 \%$ of nitrate removal was achieved. The denitrification rate at temperatures of $10-$ $18{ }^{\circ} \mathrm{C}$ decreased by $52-66 \%$ compared to that at $20-29{ }^{\circ} \mathrm{C}$. Only a small increase of DOC $\left(1.7 \pm 0.6 \mathrm{mg} \mathrm{L}^{-1}\right)$ and ammonium $(0.5$ $\pm 0.3 \mathrm{mg} \mathrm{L}^{-1}$ ) was observed in effluent which reduce the burden of post treatment. The practical PBS consumption rate $(2.75 \pm$ $0.72 \mathrm{~g} \mathrm{PBS} / \mathrm{g} \mathrm{NO}_{3}-\mathrm{N}$ ) was slightly higher than the theoretical value. Renewal of the fresh carbon source after certain period was necessary for the continuous operation. Bacteria belonging to genera Simplicispira, Veillonellaceae uncultured, Comamonadaceae uncultured and Hydrogenophaga were highly enriched in PBS biofilm. In the top 20 OTUs accounting for $25 \%$ of the total sequence, 9 OTUs belonged to denitrifying groups with an abundance of $16 \%$. Some members belonging to other 11 genera were reported to be capable of degradation and acidification of the organic substances.

\section{Conflicts of interest}

There are no conflicts to declare.

\section{Acknowledgements}

We thank the support of the project of the National Natural Science Foundation of China (51338005) and the Program for Changjiang Scholars and Innovative Research Team in University (IRT-13026).

\section{References}

1 M. N. Gonzalez-Alcaraz, H. Miguel Conesa and J. AlvarezRogel, J. Environ. Manage., 2013, 128, 964-972.

2 K. M. Hiscock, J. W. Lloyd and D. N. Lerner, Water Res., 1991, 25, 1099-1111.

3 J. Górski, K. Dragon and P. M. J. Kaczmarek, Environ. Sci. Pollut. Res., 2017, DOI: 10.1007/s11356-017-9798-3. 
4 V. Matiju, S. Cizinska, J. Krejci and T. Janoch, Enzyme Microb. Technol., 1992, 14, 170-183.

5 P. Loganathan, S. Vigneswaran and J. Kandasamy, J. Environ. Manage., 2013, 131, 363-374.

6 L. A. Schipper, W. D. Robertson, A. J. Gold, D. B. Jaynes and S. C. Cameron, Ecol. Eng., 2010, 36, 1532-1543.

7 K. A. Bill, C. B. Bott and S. N. Murthy, Water Sci. Technol., 2009, 60, 2647-2657.

8 O. Modin, K. Fukushi and K. Yamamoto, Water Res., 2007, 41, 2726-2738.

9 L. Chu and J. Wang, Chemosphere, 2013, 91, 1310-1316.

10 C. Della Rocca, V. Belgiorno and S. Meric, Desalination, 2007, 204, 46-62.

11 M. G. Healy, T. G. Ibrahim, G. J. Lanigan, A. J. Serrenho and O. Fenton, Ecol. Eng., 2012, 40, 198-209.

12 S.-M. Zhu, Y.-L. Deng, Y.-J. Ruan, X.-S. Guo, M.-M. Shi and J.-Z. Shen, Bioresour. Technol., 2015, 192, 603-610.

13 M. T. Gutierrez-Wing, R. F. Malone and K. A. Rusch, Aquacult. Eng., 2012, 51, 36-43.

14 P. Li, J. Zuo, Y. Wang, J. Zhao, L. Tang and Z. Li, Water Res., 2016, 93, 74-83.

15 S. Aslan and A. Turkman, Water Sci. Technol., 2003, 48, 489495.

16 B. Ovez, Process Biochem., 2006, 41, 1289-1295.

17 Y. Honda and Z. Osawa, Polym. Degrad. Stab., 2002, 76, 321327.

18 Z. Shen and J. Wang, Bioresour. Technol., 2011, 102, 88358838.

19 E. Walters, A. Hille, M. He, C. Ochmann and H. Horn, Water Res., 2009, 43, 4461-4468.

20 X. Zhao, X. Meng and J. Wang, Int. J. Environ. Pollut., 2009, 38, 328-338.

21 Q. Zhang, F. Ji and X. Xu, Chem. Eng. J., 2016, 283, 604-613.

22 L. Chu and J. Wang, Chemosphere, 2016, 155, 463-470.

23 O. Gibert, S. Pomierny, I. Rowe and R. M. Kalin, Bioresour. Technol., 2008, 99, 7587-7596.

24 W. Wu, L. Yang and J. Wang, Environ. Sci. Pollut. Res., 2013, 20, 333-339.

25 A. Boley and W. R. Muller, Water Sci. Technol., 2005, 52, 495502.

26 J. Wang and L. Chu, Biotechnol. Adv., 2016, 34, 1103-1112.

27 H. Zhou, X. Zhao and J. Wang, Int. J. Environ. Pollut., 2009, 38, 339-348.

28 L. Chu and J. Wang, Chem. Eng. J., 2011, 170, 220-225.

29 SEPA, Water and Wastewater Monitoring Methods, Chinese Environmental Science Publishing House, Beijing, 4th edn, 2002.

30 H. Liu and H. H. P. Fang, J. Biotechnol., 2002, 95, 249-256.

31 J. Lorenzen, L. H. Larsen, T. Kjaer and N. P. Revsbech, Appl. Environ. Microbiol., 1998, 64, 3264-3269.

32 H. Satoh, S. Okabe, N. Norimatsu and Y. Watanabe, Water Sci. Technol., 2000, 41, 317-321.

33 K. A. Karanasios, I. A. Vasiliadou, S. Pavlou and D. V. Vayenas, J. Hazard. Mater., 2010, 180, 20-37.

34 R. Canziani, R. Vismara, D. Basilico and L. Zinni, Water Sci. Technol., 1999, 40, 145-152.
35 S. G. Cameron and L. A. Schipper, Ecol. Eng., 2010, 36, 15881595.

36 C. Huilinir, S. Hernandez, E. Aspe and M. Roeckel, J. Environ. Manage., 2012, 101, 82-91.

37 Z. Ying and G. Ping, Sep. Purif. Technol., 2006, 52, 154160.

38 A. Hiraishi and S. T. Khan, Appl. Microbiol. Biotechnol., 2003, 61, 103-109.

39 S. T. Khan, Y. Horiba, M. Yamamoto and A. Hiraishi, Appl. Environ. Microbiol., 2002, 68, 3206-3214.

40 S. P. Lu, S. H. Ryu, B. S. Chung, Y. R. Chung, W. Park and C. O. Jeon, Int. J. Syst. Evol. Microbiol., 2007, 57, 31-34.

41 Y. J. Ruan, Y. L. Deng, X. S. Guo, M. B. Timmons, H. F. Lu, Z. Y. Han, Z. Y. Ye, M. M. Shi and S. M. Zhu, Bioresour. Technol., 2016, 216, 1004.

42 S. Dannenberg, M. Kroder, W. Dilling and H. Cypionka, Arch. Microbiol., 1992, 158, 93-99.

43 S. T. Khan, Y. Horiba, N. Takahashi and A. Hiraishi, Microbes Environ., 2007, 22, 20-31.

44 Z. Shen, Y. Zhou, J. Hu and J. Wang, J. Hazard. Mater., 2013, 250-251, 431-438.

45 M. Blaszczyk, Acta Microbiol. Pol., 1982, 32, 65-71.

46 N. M. Lee and T. Welander, J. Ferment. Bioeng., 1996, 82, 277285.

47 A. Neef, A. Zaglauer, H. Meier, R. Amann, H. Lemmer and K. H. Schleifer, Appl. Environ. Microbiol., 1996, 62, 43294339.

48 S. T. Khan and A. Hiraishi, J. Gen. Appl. Microbiol., 2002, 48, 299-308.

49 S. J. Andersen, P. Candry, T. Basadre, W. C. Khor, H. Roume, E. Hernandez-Sanabria, M. Coma and K. Rabaey, Biotechnol. Biofuels, 2015, 8, 1-14.

50 Z. Zhou, W. Qiao, C. Xing, X. Shen, D. Hu and L. Wang, Bioresour. Technol., 2014, 173, 452-456.

51 T. Satoh, Y. Hoshino and H. Kitamura, Arch. Microbiol., 1976, 108, 265-269.

52 D. L. Diedrich, C. A. Portnoy and S. F. Conti, Curr. Microbiol., 1983, 8, 51-56.

53 G. W. O'Hara and R. M. Daniel, Soil Biol. Biochem., 1985, 17, 1-9.

54 K. W. K. Lau, C. Y. M. Ng, J. Ren, S. C. L. Lau, P.-Y. Qian, P.-K. Wong, T. C. Lau and M. Wu, Int. J. Syst. Evol. Microbiol., 2005, 55, 1051-1057.

55 K. Heylen, B. Vanparys, L. Wittebolle, W. Verstraete, N. Boon and P. De Vos, Appl. Environ. Microbiol., 2006, 72, 2637-2643.

56 T. R. Thomsen, L. L. Blackall, M. A. de Muro, J. L. Nielsen and P. H. Nielsen, Int. J. Syst. Evol. Microbial., 2006, 56, 1865-1868.

57 R. S. Gupta, S. Mahmood and M. Adeolu, Front. Microbiol., 2013, 4, 1-18.

58 G. J. Hoogewerf, D. O. Jung and M. T. Madigan, FEMS Microbiol. Lett., 2003, 218, 359-364.

59 J. D. Noar and D. H. Buckley, Int. J. Syst. Evol. Microbiol., 2009, 59, 1941-1946. 
60 T. Narihiro, T. Terada, A. Ohashi, Y. Kamagata, K. Nakamura and Y. Sekiguchi, Water Res., 2012, 46, 2167-2175.

61 P. N. Levett, Curr. Top. Microbiol. Immunol., 2015, 387, 11-20.
62 S. Tabrez Khan and A. Hiraishi, J. Gen. Appl. Microbiol., 2002, 48, 299-308.

63 I. V. Trubitsyn, E. V. Belousova, M. N. Tutukina, A. Y. Merkel, G. A. Dubinina and M. Y. Grabovich, FEMS Microbiol. Lett., 2014, 358, 72-80. 